\title{
Innovative methods of extracting the loose gold from technogenic deposits in the Irkutsk region
}

\author{
Elena Golovina ${ }^{1, *}$, Anastasia Dykusova ${ }^{1}$, and Maxim Zhizhelev $^{1}$ \\ ${ }^{1}$ Irkutsk National Research Technical University, 664074, Lermontova str., 83, Irkutsk, Russia
}

\begin{abstract}
In Russia and abroad, the scope of the use of gold has significantly expanded, which undoubtedly affected the level of production. However, despite the fairly high rates of gold mining, the economic situation that has developed in recent years makes the companies look for new innovative placer processing technologies that will allow preserving and increasing the extraction of the precious metals. The search for and exploration of new placer gold deposits requires very considerable financial resources and time, and therefore the proposed project for the extraction of alluvial gold from technogenic deposits is of great importance for the functioning of the mining industry of the Irkutsk region, since it helps to overcome at least two negative trends: firstly, the deterioration of the mineral resource base, and secondly, large losses of gold with dump products (up to 50\%) associated with the use of obsolete washing equipment. Modernization of production capacities and processing technologies is not only one of the main factors for increasing competitiveness in the gold mining industry and attracting investors, but will also help increasing the mineral resource base of the Irkutsk region by reassessing technogenic deposits, setting gold technogenic deposits on the balance, development of technologies for technogenic deposits and processing, and involvement of technogenic deposits in the mass processing.
\end{abstract}

\section{Introduction}

In recent years, Russia has obtained leading positions in gold mining and is an advantageous partner on the global gold market. The gold mining industry is one of the most important sources of foreign currency entering the Russian economy.

In 2016, the production of gold increased in the Russian Federation, by $1.2 \%$ compared to 2015 , to 297.393 tons, including gold bullion production ( 288.6 tons) that remained at about the level of the previous year; gold in the processed products (gold-containing concentrates) sold outside the customs territory of the Russian Federation grew by $39 \%$ to 8.843 tons. In general, the production of gold from mineral raw materials increased by $3 \%$ to 262.404 tons, and gold production from scrap decreased by $9 \%$ - to 35.014 tons.

According to the Union of Manufacturers, the production of gold from mineral raw materials in Russia in 2017, as compared to 2016, will increase by $2-3 \%$ to 270 tons due to the development of existing capacities in such fields as Mayskoye and Albazinskoye

*Corresponding author: elena_uspeh@mail.ru 
(PolymetalInt); Verninskoye field (Polyus GoldInt.), Albynskoye and Malomyrskoye (PetropavlovskPlc); Dvoinoye field (KinrossGold); Gross and Berezitovoye (Nordgold); White Mountain (HighlandGold), etc., and commissioning of new facilities at Natalka (PJSC Plus, the Magadan Region), Drazhnoye (PJSC Vysochaishy, the Taryn Project, Republic of Sakha (Yakutia)), Ugakhane (PJSC Vysochaishy, the Irkutsk region), Ryabinovoye (PJSC "Seligdar", Republic of Sakha (Yakutia)) and others.

Table 1. Gold production in the Russian Federation [1].

\begin{tabular}{|c|c|c|c|c|c|c|c|}
\hline & \multirow{2}{*}{2015} & \multirow{2}{*}{2016} & \multirow{2}{*}{$\begin{array}{l}9 \text { months of } \\
2016\end{array}$} & \multirow{2}{*}{$\begin{array}{c}9 \text { months } \\
\text { of } 2017\end{array}$} & \multicolumn{2}{|c|}{$\begin{array}{c}\text { Change } 9 \text { months } \\
\text { of } 2017 \text { / } 16\end{array}$} & \multirow[t]{2}{*}{$\begin{array}{c}2018 \mathrm{~F}, \\
\text { tons }\end{array}$} \\
\hline & & & & &,$+ \mathrm{kg}$ &,$+ \%$ & \\
\hline Extracted & 232341 & 238825 & 176460 & 188763 & +12303 & +7 & \\
\hline Passing & 16604 & 14754 & 11300 & 12946 & +1646 & +14 & \\
\hline Extracted + passing & 248945 & 253579 & 187760 & 201709 & +13949 & +7 & 262 \\
\hline Secondary & 38474 & 35014 & 26360 & 27203 & +843 & +3 & \\
\hline Total: & 288991 & 288593 & 214120 & 228912 & +14792 & +7 & \\
\hline
\end{tabular}

The growth of gold extraction and production was provided by the following regions of the Russian Federation: the Chukotka Autonomous District, the Magadan region, the Republic of Sakha (Yakutia) and the Republic of Buryatia, the Khabarovsk and Kamchatka Territories, the Amur Region and others (Table 2).

Table 2. Gold mining by leading Russian regions in 2010-2016 [2].

\begin{tabular}{|c|c|c|c|c|c|c|c|c|}
\hline \multirow{2}{*}{$\begin{array}{c}\text { Constituent } \\
\text { entities of the } \\
\text { Russian } \\
\text { Federation }\end{array}$} & \multicolumn{7}{|c|}{ The value of indicators by years, $\mathrm{kg}$} & \multirow{2}{*}{$\begin{array}{l}2016 \\
2015 \\
\pm \%\end{array}$} \\
\hline & 2010 & 2011 & 2012 & 2013 & 2014 & 2015 & 2016 & \\
\hline $\begin{array}{l}\text { 1. The Krasnoyarsk } \\
\text { territory * }\end{array}$ & 36069 & 39548 & 44001 & 47326 & 47236 & 49994 & 55058 & +10 \\
\hline $\begin{array}{l}\text { 2. The Chukotka } \\
\text { AD * }\end{array}$ & 24883 & 20057 & 17988 & 21361 & 30337 & 30548 & 28820 & -6 \\
\hline $\begin{array}{l}\text { 3. The Magadan } \\
\text { region } *\end{array}$ & 15627 & 15350 & 19587 & 21092 & 23847 & 23604 & 27314 & +16 \\
\hline $\begin{array}{l}\text { 4. The Republic of } \\
\text { Sakha (Yakutia)* }\end{array}$ & 18586 & 19378 & 20826 & 21951 & 23139 & 25344 & 23505 & -7 \\
\hline 5. The Amur region & 19808 & 29111 & 28671 & 30664 & 29312 & 25946 & 22863 & -12 \\
\hline $\begin{array}{l}6 . \text { The Irkutsk } \\
\text { region }\end{array}$ & 16040 & 16990 & 18921 & 20595 & 22112 & 22104 & 22502 & +2 \\
\hline $\begin{array}{l}\text { 7. The Khabarovsk } \\
\text { Territory }\end{array}$ & 15215 & 13799 & 14799 & 20416 & 20540 & 18225 & 19847 & +9 \\
\hline $\begin{array}{l}\text { 8. Trans-Baikal } \\
\text { territory } *\end{array}$ & 6502 & 7459 & 8567 & 9452 & 9638 & 11219 & 12107 & +8 \\
\hline $\begin{array}{l}\text { 9. The Chelyabinsk } \\
\text { region. }\end{array}$ & 3646 & 3747 & 5023 & 5300 & 5573 & 6742 & 7183 & +6 \\
\hline $\begin{array}{l}10 . \text { The Kamchatka } \\
\text { territory }\end{array}$ & 2242 & 2489 & 2490 & 2214 & 2984 & 3604 & 6667 & +85 \\
\hline $\begin{array}{l}\text { 11. The Sverdlovsk } \\
\text { region }\end{array}$ & 8084 & 8179 & 7568 & 7604 & 7863 & 6411 & 6434 & 0 \\
\hline
\end{tabular}




\begin{tabular}{|c|c|c|c|c|c|c|c|c|}
\hline $\begin{array}{l}\text { 12. The Republic of } \\
\text { Buryatia }\end{array}$ & 6021 & 6505 & 5989 & 5944 & 6857 & 6235 & 5988 & -9 \\
\hline $\begin{array}{l}\text { 13. The Republic of } \\
\text { Tuva }\end{array}$ & 1446 & 1367 & 1425 & 1847 & 1936 & 2305 & 2371 & +3 \\
\hline $\begin{array}{l}\text { 14. The Republic of } \\
\text { Khakassia }\end{array}$ & 1173 & 1182 & 1629 & 2199 & 2036 & 1736 & 1964 & +13 \\
\hline $\begin{array}{l}\text { 15. The Sakhalin } \\
\text { region. }\end{array}$ & 102 & 112 & 118 & 104 & 93 & 1764 & 1582 & -10 \\
\hline $\begin{array}{l}\text { 16.The Kemerovo } \\
\text { region }\end{array}$ & 343 & 430 & 739 & 819 & 1008 & 1061 & 1487 & +40 \\
\hline $\begin{array}{l}\text { 17. The Altai } \\
\text { territory }\end{array}$ & 439 & 862 & 1088 & 971 & 715 & 736 & 698 & -5 \\
\hline $\begin{array}{l}18 . \text { The } \\
\text { Novosibirsk region }\end{array}$ & 209 & 407 & 256 & 296 & 400 & 251 & 323 & +29 \\
\hline $\begin{array}{l}\text { 19. The Republic of } \\
\text { Altai }\end{array}$ & 303 & 454 & 404 & 425 & 384 & 342 & 295 & -14 \\
\hline $\begin{array}{l}\text { 20. The Republic of } \\
\text { Bashkortostan }\end{array}$ & 399 & 285 & 323 & 204 & 177 & 204 & 243 & +19 \\
\hline $\begin{array}{l}\text { 21. The Perm } \\
\text { territory }\end{array}$ & 2 & 2 & 6 & 13 & 12 & 41 & 168 & +310 \\
\hline $\begin{array}{l}\text { 22. The Primorie } \\
\text { territory }\end{array}$ & 30 & 22 & 100 & 160 & 129 & 115 & 131 & +14 \\
\hline 23. The Jewish AD & 20 & 103 & 83 & 26 & 0 & 80 & 65 & -19 \\
\hline $\begin{array}{l}\text { 24. The Khanty- } \\
\text { Mancy AD }\end{array}$ & 45 & 236 & 99 & 88 & 85 & 47 & 28 & -40 \\
\hline $\begin{array}{l}\text { 25. The Orenburg } \\
\text { region. }\end{array}$ & 28 & & & & & & 7 & \\
\hline Total production: & $\begin{array}{c}17726 \\
2 \\
\end{array}$ & $\begin{array}{c}18807 \\
4 \\
\end{array}$ & $\begin{array}{c}20070 \\
0 \\
\end{array}$ & $\begin{array}{c}22107 \\
1 \\
\end{array}$ & $\begin{array}{c}23641 \\
3 \\
\end{array}$ & $\begin{array}{c}23865 \\
8 \\
\end{array}$ & $\begin{array}{c}24765 \\
0 \\
\end{array}$ & +4 \\
\hline In addition: passing & 12676 & 14538 & 15457 & 16005 & 16240 & 16604 & 14754 & -11 \\
\hline secondary & 12592 & 7906 & 8532 & 17764 & 35812 & 38474 & 35014 & -9 \\
\hline Total: & $\begin{array}{c}20253 \\
0\end{array}$ & $\begin{array}{c}21051 \\
8\end{array}$ & $\begin{array}{c}22466 \\
9\end{array}$ & $\begin{array}{c}25483 \\
9\end{array}$ & $\begin{array}{c}28846 \\
5\end{array}$ & $\begin{array}{c}29376 \\
8\end{array}$ & $\begin{array}{c}29741 \\
8\end{array}$ & $+1,2$ \\
\hline
\end{tabular}

* - taking into account the production of gold-containing concentrates sold on the foreign market.

However, despite fairly high rates of gold mining, the economic situation that has developed in recent years makes the companies look for new unconventional technologies for processing placers, which will allow preserving and increasing the extraction of precious metals.

In this situation, the most promising are technogenic deposits of the existing mining enterprises.

The search for and exploration of new placer gold plots requires very considerable financial resources and time. At the same time, in the areas of traditional gold mining, huge dumps of gold mining were accumulated over the past years, the technogenic deposits. They are the most important factor of increasing the mineral resource base of the alluvial gold. The representatives of three institutions, namely of science, government and business, became the participants of this investment and innovation project:

I. The initiator of this project is the Institute of the Earth's Crust of the Siberian Branch of the Russian Academy of Sciences (Institute of the Earth's Crust, Irkutsk Science Center (ISC) SB RAS).

II. Development Corporation of the Irkutsk region (The sectoral management of the Corporation is carried out by the Ministry of Economic Development of the Irkutsk region, $100 \%$ of shares are owned by the Ministry of Property Relations). 
III. Gold mining companies of the Irkutsk region; enterprises of the Irkutsk region producing concentrating equipment

The fields of interest and motivation of potential project participants are presented in the Table 4.

Table 4. Motivation of the project participants.

\begin{tabular}{|l|l|l|}
\hline № & \multicolumn{1}{|c|}{ Participant } & \multicolumn{1}{|c|}{\begin{tabular}{c}
\multicolumn{1}{|c|}{ Description of the motives for } \\
participation
\end{tabular}} \\
\hline 1 & $\begin{array}{l}\text { Institute of the Earth's Crust of SB } \\
\text { RAS }\end{array}$ & $\begin{array}{l}\text { Conducting geological exploration } \\
\text { works, obtaining scientific results, and } \\
\text { obtaining income. }\end{array}$ \\
\hline 2 & $\begin{array}{l}\text { Development Corporation of the } \\
\text { Irkutsk region }\end{array}$ & $\begin{array}{l}\text { Implementing the state environmental } \\
\text { management policy at the regional } \\
\text { level; creation of successfully operating } \\
\text { industries that will give new jobs, } \\
\text { increase regional GRP and contribute to } \\
\text { the reputation of the Irkutsk region as a } \\
\text { region with a secure investment climate } \\
\text { open for cooperation. }\end{array}$ \\
\hline 3 & $\begin{array}{l}\text { Gold mining companies of the } \\
\text { Irkutsk region (in particular, PJSC } \\
\text { Lenzoloto) }\end{array}$ & $\begin{array}{l}\text { Increase in gold production and gold } \\
\text { extraction indicators. }\end{array}$ \\
\hline 4 & $\begin{array}{l}\text { Enterprises of the Irkutsk region, } \\
\text { producing } \\
\text { equipment (in particular, LLC PC } \\
\text { "Spirit") }\end{array}$ & Expansion of the sales market. \\
\hline
\end{tabular}

\section{Materials and methods of research}

Technogenic placers are currently considered as a source of mostly fine gold, which is not captured by the sluice concentrators during primary mining. At the same time, almost every technogenic placer has elements quite suitable for profitable gold mining, and in some cases it is expedient to take into account the presence of nuggets in them.

The need to develop technogenic deposits is important from the standpoint of environment. A significant amount of toxic and potentially hazardous elements, such as mercury, arsenic, beryllium, manganese, chromium, cadmium, thallium, etc., accumulate in the waste of minerals.

At the same time, without involvement of the man-made objects in the development, there are no prospects for gold mining in Russia, in spite of its large quantity in our subsoils.

Depending on the duration of exploitation of placers in each region, there are characteristic features of technogenic reserves, which are affected by significant differences due to a number of factors, such as geological, lithodynamic, morphostructural, climatic, etc.

Technogenic placers, regardless of the primary method of exploitation, are characterized by a number of factors, contributing to their effective development. Since such placers were previously exploited and represent secondary formations, they are territorially located in already developed areas, and their development is usually associated with the restoration and improvement of the previously existing infrastructure (housing, repair bases, transport, communications, energy supply, and social services). [3]

A deterrent to the development of this direction of production activity is the need to pay taxes in the same manner, as in mining natural high-efficient stocks of raw materials. In the current system of taxation of extractive industries, tax reliefs and incentives for the rational 
use of mining and processing waste exist only in the mechanism of the mineral extraction tax. However, even there gold miners face the problem of determining the losses falling under the application of the zero rate of severance tax. Losses can be normative and over-standard. Regarding normative losses that fall within the approved figures, enterprises apply a zero percent rate for severance tax, in all other cases, $6 \%$ tax rate applies.

Also, there are difficulties referring to the legal regulation, since in accordance with the Law "On Subsoil", the development of technogenic reserves is equated with the use of subsoil with all the following procedures, i.e. unofficially operates the principle "first the calculation of reserves, then extraction, but if not yet calculated - one cannot extract". [4]

In addition, one of the reasons for the low involvement of the technogenic raw materials in processing is the high cost of extracting metals, comparable to the costs of mining traditional minerals, as well as the aging of the equipment used.

Currently, companies engaged in gold mining, face the problem of depletion of raw materials. Low profitability of such a production is more likely a consequence of obsolete technologies that developed 40-50 years ago. Consequently, the main task of such a production is to increase efficiency, which can be achieved through the automation of production, and the widespread introduction of the advanced technologies and equipment [5].

\section{Results of the study and their discussion}

Low quality of minerals of the technogenic formations processed does not allow efficient use of technologies and equipment utilized in the development of natural (geogenic) placers. Therefore, the search and justification of new technological solutions are needed.

Accordingly, the question arises about the need to involve in the processing of the manmade gold deposits not only straight-through locks, but the introduction of modern enrichment equipment capable of extracting fine gold.

On the example of the gold mining enterprises of the Irkutsk region, the analysis of the efficiency of use of concentrating equipment (the OKW - 100 LLC PC "SPIRIT" complex, mobile washing complexes (MWC), etc.) was made, from the point of view of increasing the gold extraction factor from placers, calculating the financial results, reducing costs and increasing investment attractiveness. [6]

In accordance with this, the project "Mining of alluvial gold from the technogenic deposits in the Irkutsk region" is proposed. The project has a high significance for the functioning of the mining industry of the Irkutsk region, as it helps to overcome at least two negative trends:

Firstly, the deterioration of the mineral resource base due to the lack of state funding for prospecting and evaluating the alluvial gold for several decades.

Secondly, large losses of gold with dump products (up to 50\%) associated with the use of obsolete washing equipment.

As a result, the level of taxes to the budgets of all levels is reduced, but by improving the quality and including waste from the extractive industry in processing, we can increase the level of indirect tax revenues by exporting finished products.

The investment stage of the project is two years. The required amount of investments is the following: for the first stage - 52,705,446.96 rubles; for the second stage - 135330078.00 rubles. Total is $188,035,524.96$ rubles.

The production process includes two stages: geological exploration and production. During the first year of the project, geological explorations are carried out at the selected site. In the second year, mining operations are carried out on this site. During the second year of the project, both stages will be conducted in parallel at two sites. Exploration work (geological exploration) includes the following: preparation of documentation, cameral and field work on the specific site of technogenic deposits. Every year a new site will be selected. 
The second stage - the extraction - includes the acquisition of an enrichment complex, the acquisition of mining equipment, and the preparation of a mining site and mining.

The proposed business plan is calculated at the initial price of 2400 rubles for 1 gram of gold. The Union of Gold Miners of Russia expects that the volatility of the gold price in 2017 will remain at a high level, ranging from $\$ 1,100$ to $\$ 1,350$ / oz. But overall, the forecast of the average price of gold in 2017 may be $\$ 1,270$ / oz. With a probable cross-course in the range from 58 to 65 rubles / dollar, we believe that the ruble price of gold will remain at a comfortable level for domestic companies.

Table 5. The average price of gold and the currency exchange rate in 2010-2016 [7*, $8 * *, 9 * * *]$.

\begin{tabular}{|l|l|l|l|l|l|l|l|l|}
\hline & 2010 & 2011 & 2012 & 2013 & 2014 & 2015 & 2016 &, $\pm \%$ \\
\hline $\begin{array}{l}\text { The average price of } \\
\text { gold (USD per oz.) }\end{array}$ & 1224 & 1572 & 1669 & 1410 & 1266 & 1160 & 1251 & +8 \\
\hline $\begin{array}{l}\text { The average price of } \\
\text { gold (RUB /g) ** }\end{array}$ & 1201 & 1494 & 1666 & 1435 & 1566 & 2280 & 2683 & +18 \\
\hline $\begin{array}{l}\text { The average rate of } \\
\text { RUB / USD** }\end{array}$ & 30.36 & 29.39 & 31.09 & 31.2 & 38.4 & 61.4 & 66.8 & +9 \\
\hline $\begin{array}{l}\text { RUB / USD at the end } \\
\text { of the year ** }\end{array}$ & 30.47 & 32.20 & 30.37 & 32.7 & 56.3 & 72.9 & 60.6 & -17 \\
\hline The dollar index *** & 81,35 & 76,7 & 80,58 & 81,52 & 82,66 & 91,38 & 96,87 & +6 \\
\hline
\end{tabular}

As the market research shows, the price of gold has been positive for the past 17 years, and even taking into account multidirectional dynamics, it shows an average growth of $10 \%$. The initial data for the formation of this price is the rate set by the Central Bank of Russia (based on the quotations of the London Stock Exchange). Over the past year, it fluctuated from 2212 rubles /g. to 2795 rubles / g.

The calculations for the project were settled for 8 years. The discount rate is $12 \%$. The depreciation rate is $7 \%$. At the second year the project will be at full capacity. Financial calculations and the construction of the financial and economic model of this project were carried out taking into account the following initial data (Table 7).

Table 6. Baseline data and the project assumptions.

\begin{tabular}{|l|l|l|l|l|l|l|l|l|}
\hline & 2018 & 2019 & 2020 & 2021 & 2022 & 2023 & 2024 & 2025 \\
\hline $\begin{array}{l}\text { Duration of } \\
\text { washing } \\
\text { season, days }\end{array}$ & 90 & 180 & 180 & 180 & 180 & 180 & 180 & 180 \\
\hline $\begin{array}{l}\text { The volume } \\
\text { of } \\
\text { processing } \\
\text { per day, } \mathrm{m}^{3} / \\
\text { day }\end{array}$ & 150 & 2400 & 2400 & 2400 & 2400 & 2400 & 2400 & 2400 \\
\hline $\begin{array}{l}\text { The volume } \\
\text { of } \\
\text { processing } \\
\text { for the } \\
\text { season, } \mathrm{m}^{3}\end{array}$ & 13500 & 432000 & 432000 & 432000 & 432000 & 432000 & 432000 & 000 \\
\hline $\begin{array}{l}\text { Removable } \\
\text { gold } \\
\text { content, g / } \\
\mathrm{m}^{3}\end{array}$ & 0.30 & 0.30 & 0.30 & 0.30 & 0.30 & 0.30 & 0.30 & 0.30 \\
\hline $\begin{array}{l}\text { Gold } \\
\text { production } \\
\text { per season, } \\
\text { kg }\end{array}$ & 4.1 & 129.60 & 129.60 & 129.60 & 129.60 & 129.60 & 129.60 & 129.60 \\
\hline
\end{tabular}




\begin{tabular}{|c|c|c|c|c|c|c|c|c|}
\hline $\begin{array}{l}\text { The cost of } \\
\text { gold, rubles / } \\
\text { g }\end{array}$ & $\begin{array}{l}2448.0 \\
0\end{array}$ & $\begin{array}{l}2496.9 \\
6\end{array}$ & $\begin{array}{l}2546.9 \\
0\end{array}$ & $\begin{array}{l}2597.8 \\
4\end{array}$ & $\begin{array}{l}2649.7 \\
9\end{array}$ & $\begin{array}{l}2702.7 \\
9\end{array}$ & $\begin{array}{l}2756.8 \\
5\end{array}$ & $\begin{array}{l}2811.9 \\
8\end{array}$ \\
\hline $\begin{array}{l}\text { Gold price } \\
\text { increase } \\
\text { index }\end{array}$ & $2 \%$ & $2 \%$ & $2 \%$ & $2 \%$ & $2 \%$ & $2 \%$ & $2 \%$ & $2 \%$ \\
\hline $\begin{array}{l}\text { The index of } \\
\text { price growth } \\
\text { for capital } \\
\text { expenditures }\end{array}$ & $7.1 \%$ & $5.9 \%$ & $5.2 \%$ & $5.7 \%$ & $5.7 \%$ & $6.3 \%$ & $6.2 \%$ & $6.2 \%$ \\
\hline $\begin{array}{l}\text { The wage } \\
\text { price growth } \\
\text { index }\end{array}$ & $0.0 \%$ & $5.0 \%$ & $5.0 \%$ & $5.0 \%$ & $5.0 \%$ & $5.0 \%$ & $5.0 \%$ & $5.0 \%$ \\
\hline $\begin{array}{l}\text { The income } \\
\text { price growth } \\
\text { index }\end{array}$ & $0.00 \%$ & $1.81 \%$ & $1.72 \%$ & $1.64 \%$ & $1.96 \%$ & $2.04 \%$ & $1.96 \%$ & $1.96 \%$ \\
\hline $\begin{array}{l}\text { The income } \\
\text { price growth } \\
\text { index } \\
\text { cumulative, } \\
\text { to the prices } \\
\text { of } 2017\end{array}$ & $\begin{array}{l}100.00 \\
\%\end{array}$ & $\begin{array}{l}101.81 \\
\%\end{array}$ & $\begin{array}{l}103.56 \\
\%\end{array}$ & $\begin{array}{l}105.26 \\
\%\end{array}$ & $\begin{array}{l}107.32 \\
\%\end{array}$ & $\begin{array}{l}109.51 \\
\%\end{array}$ & $\begin{array}{l}111.66 \\
\%\end{array}$ & $\begin{array}{l}113.85 \\
\%\end{array}$ \\
\hline $\begin{array}{l}\text { The index of } \\
\text { price growth } \\
\text { on operation } \\
\text { costs }\end{array}$ & $0.0 \%$ & $5.9 \%$ & $5.2 \%$ & $5.7 \%$ & $5.7 \%$ & $6.3 \%$ & $6.2 \%$ & $6.2 \%$ \\
\hline $\begin{array}{l}\text { The index of } \\
\text { price growth } \\
\text { on operation } \\
\text { costs } \\
\text { cumulative, } \\
\text { to the prices } \\
\text { of } 2017\end{array}$ & $100 \%$ & $\begin{array}{l}105.90 \\
\%\end{array}$ & $\begin{array}{l}111.41 \\
\%\end{array}$ & $\begin{array}{l}117.76 \\
\%\end{array}$ & $\begin{array}{l}124.47 \\
\%\end{array}$ & $\begin{array}{l}132.31 \\
\%\end{array}$ & $\begin{array}{l}140.51 \\
\%\end{array}$ & $\begin{array}{l}149.23 \\
\%\end{array}$ \\
\hline $\begin{array}{l}\text { The index of } \\
\text { price growth } \\
\text { on capital } \\
\text { losts, per } \\
\text { year }\end{array}$ & $0.00 \%$ & $6.30 \%$ & $5.80 \%$ & $6.70 \%$ & $7.10 \%$ & $5.90 \%$ & $5.20 \%$ & $5.20 \%$ \\
\hline $\begin{array}{l}\text { The index of } \\
\text { price growth } \\
\text { on capital } \\
\text { costs } \\
\text { cumulative, } \\
\text { to the prices } \\
\text { of } 2017\end{array}$ & $\begin{array}{l}100.00 \\
\%\end{array}$ & $\begin{array}{l}106.30 \\
\%\end{array}$ & $\begin{array}{l}112.47 \\
\%\end{array}$ & $\begin{array}{l}120.00 \\
\%\end{array}$ & $\begin{array}{l}128.52 \\
\%\end{array}$ & $\begin{array}{l}136.10 \\
\%\end{array}$ & $\begin{array}{l}143.18 \\
\%\end{array}$ & $\begin{array}{l}150.63 \\
\%\end{array}$ \\
\hline $\begin{array}{l}\text { The wage } \\
\text { price growth } \\
\text { index }\end{array}$ & $0.00 \%$ & $5.00 \%$ & $5.00 \%$ & $5.00 \%$ & $5.00 \%$ & $5.00 \%$ & $5.00 \%$ & $5.00 \%$ \\
\hline $\begin{array}{l}\text { The wage } \\
\text { price growth } \\
\text { cumulative, } \\
\text { to the prices } \\
\text { of } 2017 \text {. }\end{array}$ & $\begin{array}{l}100.00 \\
\%\end{array}$ & $\begin{array}{l}105.00 \\
\%\end{array}$ & $\begin{array}{l}110.25 \\
\%\end{array}$ & $\begin{array}{l}115.76 \\
\%\end{array}$ & $\begin{array}{l}121.55 \\
\%\end{array}$ & $\begin{array}{l}127.63 \\
\%\end{array}$ & $\begin{array}{l}134.01 \\
\%\end{array}$ & $\begin{array}{l}140.71 \\
\%\end{array}$ \\
\hline
\end{tabular}

The investment period is 2 years (Table 7). 
Table 7. The volume of investment in the project.

\begin{tabular}{|c|c|c|c|}
\hline & 2018 & 2019 & \multirow{8}{*}{$\begin{array}{l}\text { Total } \\
\text { investment }\end{array}$} \\
\hline Equipment & 8000000,00 & 45200000,00 & \\
\hline Transport and mining equipment & 9000000,00 & 79500000,00 & \\
\hline Infrastructure and communications & 2470745,00 & 6500000,00 & \\
\hline Wages & 20130000,00 & Due to current income & \\
\hline Pre-payment and closing expenses & 1332637,58 & 14000000,00 & \\
\hline $\begin{array}{l}\text { Other expenses (transport, expertise, } \\
\text { analytics) }\end{array}$ & 11772064,39 & 44478,00 & \\
\hline Income of the previous period & & 9914400,00 & \\
\hline TOTAL & 52705446,96 & 135330078,00 & $\begin{array}{l}188035 \\
524,96\end{array}$ \\
\hline
\end{tabular}

Table 8 presents the performance indicators of the proposed project

Table 8. Indicators of the project efficiency.

\begin{tabular}{|l|c|}
\hline Performance indicators & Value \\
\hline Net present value (NPV) & 201219495.98 \\
\hline Internal rate of return (IRR) & $34.0 \%$ \\
\hline Payback period without credits & 2.11 \\
\hline Investment profitability & $47.39 \%$ \\
\hline
\end{tabular}

The project has fairly high performance indicators. It pays off already on the third year of implementation. In addition, return on the investment is more than $47 \%$.

\section{Conclusion}

The identified problems - the use of obsolete equipment by most artisanal artels and the incompleteness of extracting gold ores from the subsoil (placers) often contribute to reducing the investment potential of the industry.

In this situation, it is advisable to introduce the latest equipment and innovative processing technologies in gold mining, which will provide for involving ore and placers with lower quality indicators into processing, and allow reducing losses of fine gold and increasing the completeness of placer mining. Modernization of production capacities and processing technologies is one of the main factors for increasing competitiveness in the industry and attracting investors.

The search for and exploration of new placer gold plots requires very considerable financial resources and time. At the same time, in the areas of traditional gold mining, there are huge dumps of gold mining of the past years, the technogenic deposits. They are the most important reserve of increasing the mineral and raw materials base of alluvial gold. During the history of gold mining in Russia, about 12 thousand tons of gold, including some $85 \%$ or about 10 thousand tons of gold was extracted from placer deposits. Annually, as the placers are being worked out, the resources of gold in the technogenic placers of the Russian Federation increase by no less than 20 tons.

According to the data of the Federal Agency for Subsoil Use, the mineral and raw materials base of gold, platinum group metals, silver and diamonds is quite large. It is in demand and will not be exhausted up to 2040. It should guarantee economically sound levels of production, which can vary depending on the situation in the country and in the world. 
This base, inter alia, should ensure the possibility of a rapid growth of production during the periods of rising prices for precious metals and diamonds. It should also be taken into account that, in a number of remote regions of Russia, gold and diamond deposits play an important social and geopolitical role, providing the "Russian presence" and employment of the population. However, despite this circumstance, it is necessary to take into account various parameters of economic, political, environmental and social nature that can negatively affect the amount of revenues to the budget from direct extraction and further development of the extractive industry as a whole. Since in recent years the issue of environmental safety has been increasingly raised, many states are interested in alternative methods of extraction and processing raw materials, which include, inter alia, the introduction of innovative technologies that make it possible to use technogenic deposits from primary mining.

\section{References}

1. Ministry of Finance of Russia (www.minfin.ru, 2017)

2. E. Drolova, V. Butakova, Collection of materials of the $V$ regional scientific and practical conference, 198-200, (2015)

3. The development of industrial processing of man-made raw materials in Russia, the round table of the State Duma Committee on Natural Resources, Nature Management and Ecology and the Higher Mining Council of the Non-Profit Partnership "Mining Industrialists of Russia," (2017)

4. Yu. Mamaev, V. Litvintsev, A. Van-Van-E, Problems and Prospects, 53-56 (1997)

5. Gold mining: technologies and equipment for professionals and amateurs: on increasing the efficiency of alluvial gold mining (http://zolotodb.ru, 2017)

6. Materials of the Production Company SPIRIT LLC. (www. spirit.irk.ru, 2017)

7. Official site of the London Bullion Market Association (www.lbma.org.uk, 2017)

8. The official website of the Bank of Russia (www.cbr.ru, 2017)

9. Information portal (www.ru.investing.com, 2017)

10. A. V. Bogoviz, Y. V. Ragulina, N. V. Sirotkina, Advances in Intelligent Systems and Computing, 622, 597-602 (2018) 